\title{
Correction to: K-haler breath-triggered inhaler: a profile of the properties of the device
}

\author{
Emma D. Deeks ${ }^{1} \cdot$ Katherine A. Lyseng-Williamson $^{1}$ (i)
}

Published online: 24 July 2019

(c) Springer Nature 2019

\section{Correction to: Drugs \& Therapy Perspectives (2019) 35:315-320 https://doi.org/10.1007/s40267-019-00635-7}

The article K-haler ${ }^{\circledR}$ breath-triggered inhaler: a profile of the properties of the device, written by Emma D. Deeks and Katherine A. Lyseng-Williamson, was originally published Online First without open access. After publication in volume 35, issue 7, pages 315-320, Mundipharma International Limited requested that the article be Open Choice to make the article an open access publication. Post-publication open access was funded by Mundipharma International Limited. The article is forthwith distributed under the terms of the Creative Commons Attribution-NonCommercial 4.0 International License (http://creativecommons.org/licen ses/by-nc/4.0/), which permits any noncommercial use, duplication, adaptation, distribution and reproduction in any medium or format, as long as you give appropriate credit to the original author(s) and the source, provide a link to the Creative Commons license and indicate if changes were made.

The original article has been updated.

Open Access This article is distributed under the terms of the Creative Commons Attribution 4.0 International License (http://creativecommons. org/licenses/by/4.0/), which permits unrestricted use, distribution, and reproduction in any medium, provided you give appropriate credit to the original author(s) and the source, provide a link to the Creative Commons license, and indicate if changes were made.

The original article can be found online at https://doi.org/10.1007/ s40267-019-00635-7.

Katherine A. Lyseng-Williamson

dtp@adis.com

1 Springer, Private Bag 65901, Mairangi Bay, Auckland 0754, New Zealand 